\title{
Morphobiological Characterization of Trypanosoma cruzi Chagas, 1909 and its Distinction from other Trypanosomes
}

\author{
Maria Auxiliadora de Sousa
}

Coleção de Tripanosomatídeos, Laboratório de Transmissores de Hematozoários, Departamento de Entomologia, Instituto Oswaldo Cruz, Av. Brasil 4365, 21045-900 Rio de Janeiro, RJ, Brasil

Key words: Trypanosoma cruzi - Trypanosoma rangeli - Trypanosoma conorhini - Trypanosoma lewisi Trypanosoma minasense - Trypanosoma freitasi - Chagas disease - morphobiology - characterization

The etiologic agent of the human American trypanosomiasis was discovered by Chagas (1909a) initially in triatomine bugs, Panstrongylus megistus, collected in Lassance, State of Minas Gerais, Brazil. Its infectivity to some laboratory animals was soon confirmed, a peculiar small trypanosome appearing in the blood of these animals, which Chagas (1909a) named Trypanosoma cruzi in honor of Oswaldo Cruz. The first natural infection of a mammal with $T$. cruzi was recorded in a cat also by Chagas (1909b), who subsequently found the parasite in the blood of a child, and associated to it the illness found in that child, as well as in other persons living in houses infested with triatomine bugs in Lassance. At that time, Chagas (1909b) also carried out studies on this parasite in human beings, experimental mammal hosts, triatomines and axenic cultures. Believing that $T$. cruzi presented schizogonic stages in the lungs of vertebrate hosts, Chagas (1909b) temporarily placed it in a new genus, Schizotrypanum, but subsequently corrected such mistake (Chagas 1913). Chagas $(1912,1924)$ also found T. cruzi in wild animals, armadillos (incriminating $P$. geniculatus as its vector) and squirrel monkeys. The evolution of $T$. cruzi in Triatoma infestans and the possibility of this species and $T$. sordida actuating as vectors were also reported by Chagas (1912).

Hartmann (1910) and Vianna (1911) discovered the intracellular multiplication of T. cruzi, but the latter correctly interpreted it as occurring by binary fission. Vianna (1911) carried out an extensive histopathological study in post-mortem patients and experimental animals, evidencing the parasite multiplication in several tissues, mainly myocardium and skeletal muscles. Brumpt (1912) studied the development of T. cruzi in P. megistus,

Fax: +55-21-290.9339 or 598.4320.

E-mail: masousa@gene.dbbm.fiocruz.br

Received 9 June 1999

Accepted 9 August 1999 cimicids and ticks, discovering the infectivity to mammals of the trypomastigotes found in the posterior intestine and in the feces (metacyclics). An important revision of $T$. cruzi biology was undertaken by Dias (1934), being noteworthy his detailed study on the parasite development in triatomines. The name Schizotrypanum as subgenus, $T$. (S.) cruzi being the type species, became largely accepted after Hoare's reviews on mammal trypanosomes $(1964,1972)$. More recently, an interesting aspect of $T$. cruzi biology was described by Deane et al. (1984), who discovered stages typically found in triatomines also in the lumen of anal glands of the opossum Didelphis marsupialis.

The intraspecific variability of T. cruzi was early known and can be easily verified by morphobiological approaches. Such variability is not surprising for a parasite having so wide geographic distribution in the American Continent and so great diversity of hosts, which can actuate as biological filters on its natural populations. It is worthy mentioning that more than 200 species/subspecies of mammals and more than 70 species of triatomines have been reported as T. cruzi hosts (Deane 1961, 1964, Barreto \& Ribeiro 1979, Sherlock et al. 1997). Some authors have provided evidences that genetic exchange may also contribute to diversity in T. cruzi (Bogliolo et al. 1996, Carrasco et al. 1996). However, despite its great variability, it has been largely accepted that $T$. cruzi can be identified by a set of features, which have been summarized also by Barreto and Ribeiro (1979): (1) infectivity to common laboratory mammals, mainly young mice, rats and guinea-pigs, being this verified either directly by blood examination or indirectly by hemoculture and xenodiagnosis; (2) small size and peculiar morphological features of the bloodstream trypomastigotes, the more remarkable one being the large round kinetoplast (Fig. 1: AC); (3) infectivity to triatomines, in their mid- and hindgut mainly occurring as epimastigotes, and in the latter also as peculiar slim metacyclic trypomastigotes (17-22 $\mathrm{mm}$ in length, according to Hoare 1972) which have a large round subter- 
minal kinetoplast (Fig. 2: H6, 7); (4) easy growth at about $27^{\circ} \mathrm{C}$ in several conventional culture media (NNN, LIT, Warren, and so on), presenting stages similar to those found in triatomines (Fig. 2: H); (5) capacity for intracellular multiplication as amastigotes, either in mammal host tissues or cellular cultures, subsequently originating trypomastigotes similar to the blood forms.

Aiming to confirm whether new isolates are or not T. cruzi, several authors have also used or suggested the use of "protection assays" (Dias 1935, Barreto \& Ribeiro 1979, Marinkelle 1982, Steindel et al. 1998). Otherwise, as the epimastigotes of $T$. cruzi, either from insect gut or axenic cultures, are susceptible to complement lysis (Muniz \& Borriello 1945), this test can be additionally used for its characterization. Isolates (from mammals or triatomines) which have features of the subgenus Schizotrypanum, while partially characterized, have been usually identified as T. cruzi-like organisms. The validity of those species proposed to some $T$. cruzi-like trypanosomes found in non-human primates ( $T$. prowazeki, $T$. lesourdi, $T$. sanmartini) is matter of discussion, they not being largely accepted (Deane 1964, Hoare 1972, Marinkelle 1976b).

The occurrence of $T$. cruzi-like organisms in American bats is a problem to be considered in epidemiological studies on the agent of Chagas disease. Whereas being largely accepted that $T$. cruzi occurs in bats as well (Clark \& Dunn 1932, Deane 1961, 1964, Hoare 1972, Marinkelle 1976a, 1982, Barreto \& Ribeiro 1979), new T. (Schizotrypanum) species/subspecies were proposed to several isolates from chiropterans mainly based on their apparent lack of infectivity to common laboratory animals and/or triatomines, as well as on morphological peculiarities (reviewed by Dias 1935, Hoare 1972, Marinkelle 1976a, Molyneux 1991). However, the state of our knowledge about these organisms is yet unsatisfactory and comparative studies using well-characterized T. cruzi strains are necessary to better establish their distinction. Otherwise, the actual host-restriction of some Schizotrypanum species from bats should be confirmed, at least by examining for periods longer than 60 days those hemocultures from experimentally inoculated laboratory animals.

According to Hoare (1972), the mean total length of the bloodstream trypomastigotes in several T. cruzi isolates, either from natural or experimental hosts, ranged from 16.3 to $21.8 \mu \mathrm{m}$. The morphological variability of these trypomastigotes was early noted by Chagas (1909b), who described the slender (Fig. 1: A1, B3, C1) and broad (Fig. 1: A2, B1, C3) forms. However, other types, as short (Fig. 1: B2), very broad (Fig.1: C4, 5) and inter- mediate forms (Fig. 1: A3, C2) can also be found (Silva 1959, Brener \& Chiari 1963). The rate of these forms varies according to the parasite strain, the phase of infection, as well as the host species (Silva 1959, Brener 1965, Andrade 1974, Sogayar 1978, Urdaneta-Morales 1983). Brener (1965) and Andrade (1974) grouped some T. cruzi strains according to the predominance of each form and their behavior in experimentally infected mice, mainly considering the pattern of parasitemia, predominant lesions or tissue parasitism, virulence and lethality. However, those groupings can not be correlated to each other at all; for example, those strains predominantly presenting stout forms, producing increasing parasitemia and high mortality in mice (Brener 1965, Carneiro et al. 1991) do not fit in with the strain types (biodemes) proposed by
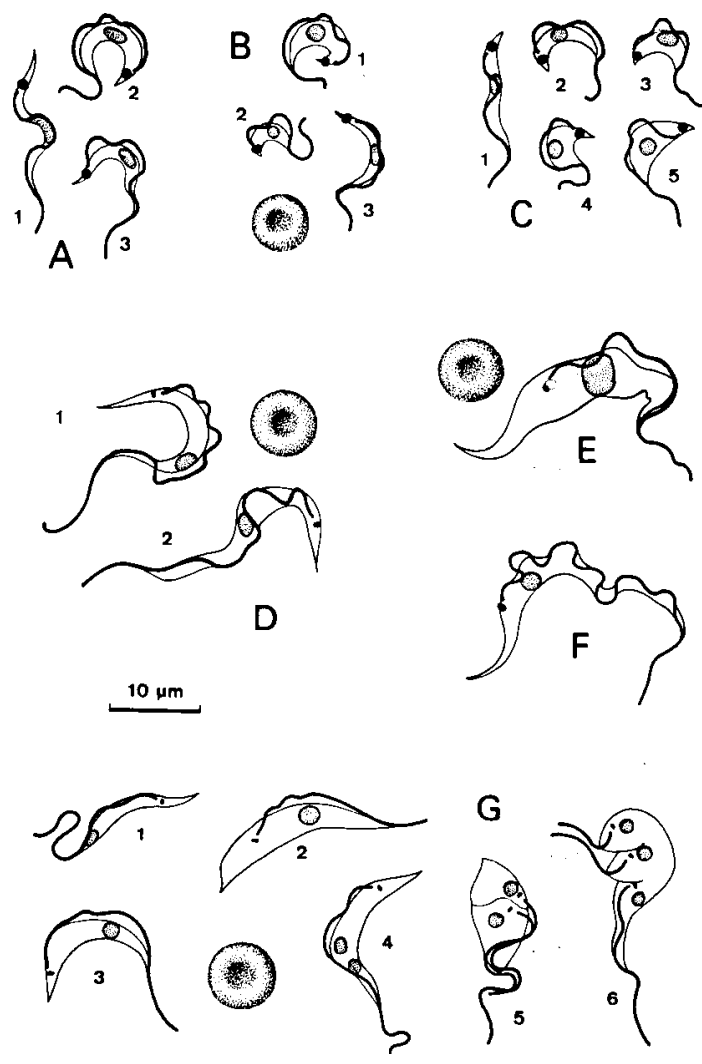

Fig. 1 - A, B, and C: Trypanosoma cruzi, Y, FL and CL strains, respectively, forms from the blood of experimentally infected mice. D: T. rangeli; 1 : bloodstream trypomastigotes from naturally infected Saimiri ustus; 2: blood forms from experimentally infected Callithrix jacchus. E: T. minasense, bloodstream stage from naturally infected $C$. penicillata. F: T. conorhini, bloodstream type trypomastigote from the supernatant of parasite co-culture with L929 cell line at $37^{\circ} \mathrm{C}$. G: T. lewisi, stages from the blood of experimentally infected rat; 5-6 are dividing epimastigotes. Red blood cells from mouse, squirrel monkey, marmoset and rat are shown for comparison in B, D, E and G, respectively. Camera lucida drawings from Giemsa-stained smears. 
Andrade (1974). Otherwise, T. cruzi strains determining only subpatent parasitemia in mice can not be considered according to those parameters.

Some studies have suggested that the different T. cruzi blood forms may have also different biological roles and that, at least partially, the features of a strain may depend on the predominance of one of them (Brener 1965, 1969). Several authors provided evidences that the slender forms would be more fitted for cellular invasion, whereas the broad ones would more promptly develop in triatomines or axenic cultures (Silva 1959, Brener 1969, Howells \& Chiari 1975, Deane 1979, Sousa et al. 1982, Schmatz et al. 1983). However, Deane (1979) emphasized the possible occurrence of undifferentiated or ambivalent bloodstream trypomastigotes, perhaps represented by the socalled intermediate forms, which would develop either inside cells or in axenic cultures. Brener and Chiari (1965) also reported that the pattern of early growth in culture (or citrated blood) at $28^{\circ} \mathrm{C}$ of different $T$. cruzi strains varied according to their predominant blood form.

Since $T$. cruzi has a notable range of hosts, it is not infrequent that these can be parasitized by other trypanosomes, and that mixed infections can occur when their geographic distribution overlaps. It is frequently possible to distinguish these trypanosomes from T. cruzi by classical morphobiological approaches, and herein some of them are reported with emphasis on useful features to their differential diagnosis. Aiming at a more complete characterization of these trypanosomes or knowledge of other species some important reviews (Hoare 1972, D'Alessandro 1976, Marinkelle 1976a, b, Molyneux 1976, 1991, Wells 1976, D'AlessandroBacigalupo \& Saravia 1992) and original papers should be consulted. It is worthy mentioning that those morphobiological approaches are not in opposition to the use of biochemical and molecular techniques to characterize and identify these trypanosomes, but rather they greatly contribute for a more wide and comprehensive view of their evolution and taxonomy.

T. rangeli Tejera, 1920 is a non-pathogenic trypanosome of human beings and several mammals transmitted through inoculative route by some triatomine species (mainly genus Rhodnius), and frequently shares hosts with T. cruzi (Hoare 1972, D'Alessandro 1976, D’ Alessandro-Bacigalupo \& Saravia 1992). Although the natural or experimental mammal hosts of $T$. rangeli (or $T$. rangeli-like parasites) usually display low or subpatent parasitemia, its bloodstream trypomastigotes can be distinguished from those of $T$. cruzi mainly by their larger size and smaller kinetoplast (Fig. 1: D1, 2). According to D'Alessandro (1976) the mean total length of $T$. rangeli blood forms from various reports ranged from 26.4 to $33.8 \mu \mathrm{m}$. No multiplication site of this parasite in mammals has been convincingly demonstrated (D'Alessandro-Bacigalupo \& Saravia 1992). In triatomine bugs, T. rangeli develops in the intestine, but unlike T. cruzi, can invade the hemocele, as well as the salivary glands, where large number of metacyclics are formed. These are small and broad trypomastigotes, 8-13 $\mu \mathrm{m}$ in length (D'Alessandro 1976), with an inconspicuous undulating membrane, a subterminal and a relatively large kinetoplast (Fig. 2: J11). T. rangeli can also be cultivated in conventional liquid media usually overlaying blood-agar slants, but it is more exigent than T. cruzi to be maintained by serial transfers. Either in triatomines or in recently isolated cultures (at about $27^{\circ} \mathrm{C}$ ), T. rangeli can be very polymorphic, presenting small epimastigotes or aflagellate forms (Fig. 2: J1, 2), medium-sized epi- or trypomastigotes (Fig. 2: J5-7), peculiar long epi- and trypomastigotes (which may reach 100 $\mu \mathrm{m}$ or more, according to D'Alessandro, 1976) (Fig. 2: J3, 4, 8), besides metacyclic trypomastigotes (Fig. 2: J9-11). Several T. rangeli-like trypanosomes were described as separate species ( $T$. diasi, T. mycetae, T. myrmecophagae, T. saimirii, and so on), but their taxonomic status has been discussed by several authors (Deane \& Damasceno 1961, Hoare 1972, D'Alessandro 1976, D'Alessandro-Bacigalupo \& Saravia 1992, Ziccardi \& Lourenço-de-Oliveira 1998).

T. (Herpetosoma) lewisi (Kent 1880) is a common parasite of rats in various parts of the world (Rattus rattus, $R$. norvegicus and others), being transmitted by fleas; it is normally host-restricted, confined to rats, and non-pathogenic (Hoare 1972, Molyneux 1976). Its bloodstream trypomastigotes are very distinct from those of $T$. cruzi, usually having the nucleus anteriorly placed, the small rodlike kinetoplast and the poorly-developed membrane undulating (Fig. 1: G1-3). During its reproductive phase, T. lewisi multiplies in the blood (as epimastigotes) mainly by successive unequal divisions (Fig. 1: G5, 6). Following this phase only monomorphic trypomastigotes ("adults") remain in the blood; their mean total length is $30.6 \mu \mathrm{m}$ (Hoare 1972). T. lewisi does not develop in triatomines, but can growth in axenic cultures at about $27^{\circ} \mathrm{C}$ (Hoare 1972, Molyneux 1976). There are several T. lewisi-like trypanosomes described under other specific names ( $T$. forattinii, $T$. coutinhoi, and so on) and which were only partially studied (Deane 1961, Hoare 1972).

T. (Megatrypanum) conorhini (Donovan, 1909) is another common parasite of rats ( $R$. rattus) and possibly of non-human primates, being transmitted by Triatoma rubrofasciata; it is easily culti- 

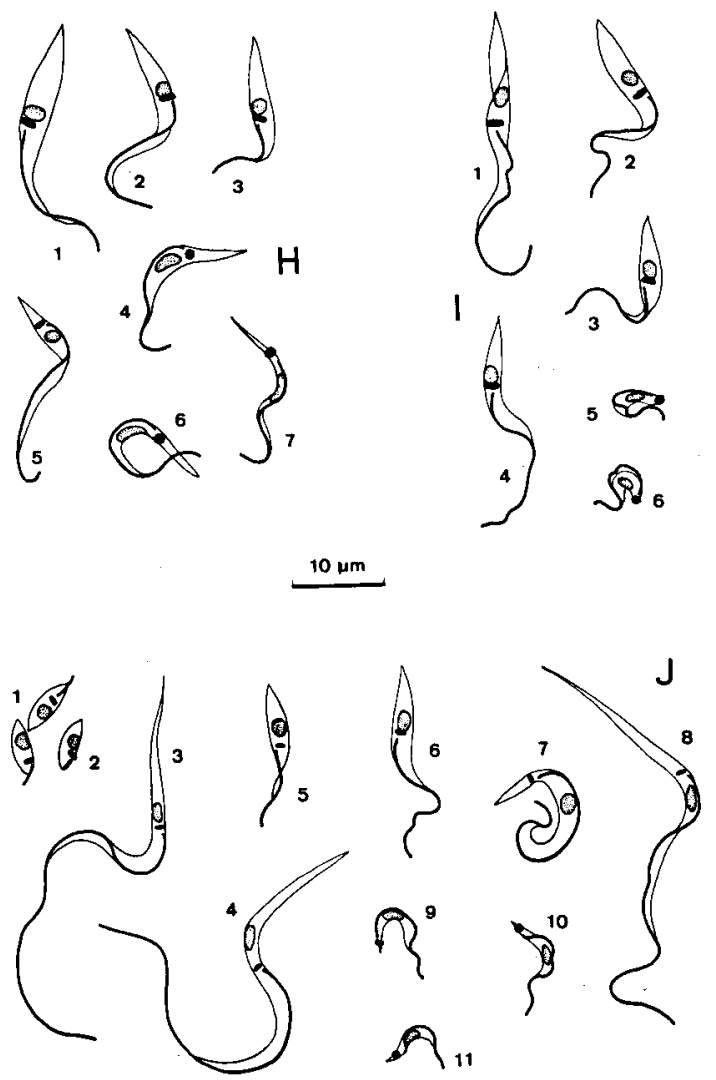

Fig. 2- H: Trypanosoma cruzi, CL strain in axenic culture; 1-3: epimastigotes; 4-5: transitional trypomastigotes; 6-7: metacyclics. I: T. conorhini, Lourenço-de-Oliveira/Ziccardi strain in axenic culture; $1-4$ : epimastigotes; 5 : transitional stage to metacyclic; 6: metacyclic. J: T. rangeli, SC 58 strain; 1-10 stages from a recently isolated culture; 1 : small epimastigotes; 2: small aflagellate form; 3-6: epimastigotes; 7-8: trypomastigotes; 9-10: metacyclic-like trypomastigotes; 11 : metacyclic from salivary glands of experimentally infected Rhodnius prolixus. Camera lucida drawings. All cultures were maintained at about $27^{\circ} \mathrm{C}$. Giemsa-stained smears after $\mathrm{HCl}$ digestion.

vated and can experimentally infect some laboratory animals and other triatomine species (Dias \& Seabra 1943, Deane 1947, Deane \& Deane 1961, Hoare 1972, Deane et al. 1986). Parasitemia in natural or experimental hosts is usually scanty or subpatent. T. conorhini bloodstream forms are large trypanosomes, 36-62 $\mu \mathrm{m}$ in total length, which have a medium-sized kinetoplast usually far from its pointed posterior end, and a well-developed undulating membrane (Fig. 1: F) (Hoare 1972). In axenic cultures at nearly $27^{\circ} \mathrm{C}$, as in triatomines, besides epimastigotes, peculiar metacyclic trypomastigotes can be found (Fig. 2: I). These metacyclics are usually very short and stumpy forms (average $<10 \mathrm{~mm}$, according to Deane \& Deane 1961), having an inconspicuous undulating membrane and a large ter- minal kinetoplast (Fig. 2: I6); they seem to arise from spheromastigotes by an unrolling process (Fig. 2: I5).

Other species belonging to the Megatrypanum subgenus, as T. minasense (Fig. 1: E) from nonhuman primates, $T$. freitasi from opossums, $T$. leonidasdeanei and T. pessoai from bats, are also easily distinguished from $T$. cruzi by their large bloodstream forms, non-infectivity for mice, hard or no growth in triatomines and in conventional culture media (Deane \& Damasceno 1961, Hoare 1972, Marinkelle 1976a, b, Molyneux 1991, Ziccardi et al. 1996). However, T. freitasi can also be found in the lumen of anal glands of opossums (Deane \& Jansen 1990).

\section{ACKNOWLEDGMENTS}

To Profs Dayse CB Branco and Glória MC Gonçalves for helping in the illustrations. To Drs Mario Steindel, Mariangela Ziccardi, Neide Thomaz for providing some materials used in the illustrations. To Dr Wladimir Lobato Paraense for reviewing the manuscript.

\section{REFERENCES}

Andrade SG 1974. Caracterização de cepas do Trypanosoma cruzi isoladas no Recôncavo Baiano. Rev Pat Trop 3: 65-121.

Barreto MP, Ribeiro RD 1979. Reservatórios silvestres do Trypanosoma (Schizotrypanum) cruzi Chagas 1909. Rev Inst Adolfo Lutz 39: 25-36.

Bogliolo AR, Lauria-Pires L, Gibson WC 1996. Polymorphisms in Trypanosoma cruzi: evidence of genetic recombination. Acta Trop 61: 31-40.

Brener Z 1965. Comparative studies of different strains of Trypanosoma cruzi. Ann Trop Med Parasitol 59: 19-26.

Brener Z 1969. The behaviour of slender and stout forms of Trypanosoma cruzi in the blood-stream of normal and immune mice. Ann Trop Med Parasitol 63: 215-220.

Brener Z, Chiari E 1963. Variações morfológicas observadas em diferentes amostras de Trypanosoma cruzi. Rev Inst Med Trop São Paulo 5: 220-224.

Brener Z, Chiari E 1965. Aspects of early growth of different Trypanosoma cruzi strains in culture medium. J Parasitol 51: 922-926.

Brumpt E 1912. Le Trypanosoma Cruzi évolue chez Conorhinus megistus, Cimex lectularius, Cimex Boueti et Onithodorus moubata. Cycle évolutif de ce parasite. Bull Soc Pathol Exot 5: 360-367.

Carneiro M, Romanha AJ, Chiari E 1991. Biological characterization of Trypanosoma cruzi strains from different zymodemes and schizodemes. Mem Inst Oswaldo Cruz 86: 387-393.

Carrasco HJ, Frame IA, Valente SA, Miles MA 1996. Genetic exchange as a possible source of genomic diversity in sylvatic populations of Trypanosoma cruzi. Amer J Trop Med Hyg 54: 418-424.

Chagas C 1909a. Neue Trypanosomen. Arch Schiffs Tropenhyg 13: 120-122. 
Chagas C 1909b. Nova tripanozomiaze humana. Estudos sobre a morfolojia e o ciclo evolutivo do Schizotrypanum cruzi n. gen, n. sp., ajente etiolojico de nova entidade morbida do homem. Mem Inst Oswaldo Cruz 1: 11-80.

Chagas C 1912. Sobre um trypanosomo do tatú, Tatusia novemcincta, transmittido pela Triatoma geniculata Latr. (1811). Possibilidade de ser o tatú um depositario do Trypanosoma Cruzi no mundo exterior. Brazil-Med I: 305-306.

Chagas C 1913. Revisão do cyclo evolutivo do "Trypanosoma Cruzi”. Brazil-Med 27: 225.

Chagas C 1924. Sobre a verificação do "Trypanosoma cruzi” em macacos do Pará (Chrysothrix sciureus). Scien Med 2: 75-76.

Clark HC, Dunn LH 1932. Experimental studies on Chagas disease in Panama. Am J Trop Med 12: 4977.

D’Alessandro A 1976. Biology of Trypanosoma (Herpetosoma) rangeli Tejera, 1920, p. 327-403. In WHR Lumsden \& DA Evans (eds), Biology of the Kinetoplastida, vol 1, Academic Press, London.

D’Alessandro-Bacigalupo A, Saravia NG 1992. Trypanosoma rangeli, p. 1-54. In JP Kreier, JR Baker (eds), Parasitic Protozoa, 2nd ed, vol 2, Academic Press, San Diego.

Deane LM 1961. Tripanosomídeos de mamíferos da região Amazônica. I. Alguns flagelados encontrados no sangue de mamíferos silvestres do Estado do Pará. Rev Inst Med Trop São Paulo 3: 15-28.

Deane LM 1964. Animal reservoirs of Trypanosoma cruzi in Brazil. Rev Bras Malariol D Trop 16: $27-$ 48.

Deane LM, Damasceno RG 1961. Tripanosomídeos de mamíferos da Região Amazônica. II. Tripanosomas de macacos da Zona do Salgado, Estado do Pará. Rev Inst Med Trop São Paulo 3: 61-70.

Deane LM, Deane MP, Lourenço-de-Oliveira R 1986. Are asian monkeys the original hosts of Trypanosoma conorhini? Mem Inst Oswaldo Cruz 81: 127129.

Deane MP 1947. Ocorrência do Trypanosoma conorrhini em "barbeiros" e em rato na cidade de Belém, Pará, e seu cultivo em meio NNN. Rev Ser Esp Saúde Públ 1: 433-442.

Deane MP 1979. Significance of polymorphism in Trypanosoma cruzi, p. A6-7. Anais do Congresso Internacional sobre Doença de Chagas, Rio de Janeiro.

Deane MP, Deane LM 1961. Studies on the life cycle of Trypanosoma conorrhini. "In vitro" development and multiplication of the bloodstream trypanosomes. Rev Inst Med Trop São Paulo 3: 149-160.

Deane MP, Jansen AM 1990. Developmental stages of Trypanosoma (Megatrypanum) freitasi Rego, Magalhães \& Siqueira, 1957 in the opossum Didelphis marsupialis (Marsupialia, Didelphidae). $J$ Protozool 37: 44-47.

Deane MP, Lenzi HL, Jansen A 1984. Trypanosoma cruzi: vertebrate and invertebrate cycles in the same mammal host, the opossum Didelphis marsupialis. Mem Inst Oswaldo Cruz 79: 513-515.
Dias E 1934. Estudos sobre o Schizotrypanum cruzi. Mem Inst Oswaldo Cruz 28: 1-110.

Dias E. 1935. Revisão geral dos hemoflagellados de Chirópteros, p. 10-88. Novena Reunión de la Sociedad Argentina de Patologia Regional, Mendoza.

Dias E, Seabra CAC 1943. Sôbre o Trypanosoma conorrhini, hemoparasito do rato transmitido pelo Triatoma rubrofasciata. Presença do vector infectado na cidade do Rio de Janeiro. Mem Inst Oswaldo Cruz, 39: 301-330.

Hartmann M 1910. Notiz über eine weitere art der schizogonie bei Schizotrypanum cruzi (Chagas). Arch Protistenk 20: 361-363.

Hoare CA 1964. Morphological and taxonomic studies on mammalian trypanosomes. X. Revision of the systematics. J Protozool 11: 200-207.

Hoare CA 1972. The Trypanosomes of Mammals. A Zoological Monograph. Blackwell Scientific Publication, Oxford.

Howells RE, Chiari CA 1975. Observations on two strains of Trypanosoma cruzi in laboratory mice. Ann Trop Med Parasitol 69: 435-448.

Marinkelle CJ 1976a. Biology of the trypanosomes of bats, p. 175-216. In WHR Lumsden, DA Evans (eds), Biology of the Kinetoplastida, vol 1, Academic Press, London.

Marinkelle CJ 1976b. The biology of the trypanosomes of non-human primates, p. 217-256. In WHR Lumsden, DA Evans (eds), Biology of the Kinetoplastida, vol 1, Academic Press, London.

Marinkelle CJ 1982. Prevalence of Trypanosoma cruzilike infection of Colombian bats. Ann Trop Med Parasitol 76: 125-134.

Molyneux DH 1976. Biology of trypanosomes of the subgenus Herpetosoma, p. 285-325. In WHR Lumsden, DA Evans (eds), Biology of the Kinetoplastida, vol 1, Academic Press, London.

Molyneux DH 1991. Trypanosomes of bats, p. 195-223. In JP Kreier, JR Baker (eds), Parasitic Protozoa, 2nd ed, vol 1, Academic Press, San Diego.

Muniz J, Borriello A 1945. Estudo sôbre a ação lítica de diferentes sôros sôbre as formas de cultura e sanguícolas do "Schizotrypanum cruzi". Rev Brasil Biol 5: 563-576.

Schmatz DM, Boltz RC, Murray PK 1983. Trypanosoma cruzi: separation of broad and slender trypomastigotes using a continuous hypaque gradient. Parasitology 87: 219-227.

Sherlock IA, Carcavallo RU, Girón IG 1997. List of natural and experimental flagellate infections in several triatominae species, p. 289-298. In RU Carcavallo, IG Girón, J Jurberg, H Lent (eds), Atlas dos Vetores da Doença de Chagas nas Américas, vol I, Fiocruz, Rio de Janeiro.

Silva LHP 1959. Observações sôbre o ciclo evolutivo do Trypanosoma cruzi.Rev Inst Med Trop São Paulo 1: 99-118.

Sogayar R 1978. Infecção Experimental de Ratos Albinos Wistar com Diferentes Cepas de Trypanosoma cruzi Chagas 1909, MSc Thesis, Universidade Federal of Minas Gerais, Belo Horizonte, 100 pp. 
Sousa MA, Brito CMM, Alencar AA 1982. Aspectos do comportamento biológico de tripomastigotas sangüíneos finos e largos de uma mesma cepa de Trypanosoma cruzi, p. 138. Anais da IX Reunião Anual sobre Pesquisa Básica em Doença de Chagas, Caxambu, MG, Brazil.

Steindel M, Grisard EC, Pinto CJC, Cordeiro FD, RibeiroRodrigues R, Romanha AJ 1998. Characterization of trypanosomes from the subgenus Schizotrypanum isolated from bats, Eptesicus sp. (Chiroptera: Vespertilionidae), captured in Florianópolis, Santa Catarina State, Brazil. J Parasitol 84: 601-607.

Urdaneta-Morales S 1983. Pleomorphism in trypomastigotes of Trypanosoma cruzi from blood and cell culture. Tropenmed Parasit 34: 225-228.

Vianna G 1911. Contribuição para o estudo da anatomia patolojica da "Molestia de Carlos Chagas". Mem Inst Oswaldo Cruz 3: 276-294.

Wells EA 1976. Subgenus Megatrypanum, p. 257-284. In WHR Lumsden, DA Evans (eds), Biology of the Kinetoplastida, vol 1, Academic Press, London.

Ziccardi M, Lourenço-de-Oliveira R 1998. Morphological features of trypanosomes from squirrel monkeys from the Brazilian Amazon. Mem Inst Oswaldo Cruz 93: 45-55.

Ziccardi M, Lourenço-de-Oliveira R, Nogueira R 1996. The haemoculture of Trypanosoma minasense Chagas 1908. Mem Inst Oswaldo Cruz 91: 501-505. 